\title{
Evaluating Student and Teacher Views on The Use of Authentic Learning in Primary School Social Studies Course: A Case Study
}

\author{
Hanifi Şekerci* \\ Department of Basic Education, University of Dicle, Diyarbaktr, Turkey
}

ORCID: 0000-0002-1280-3228

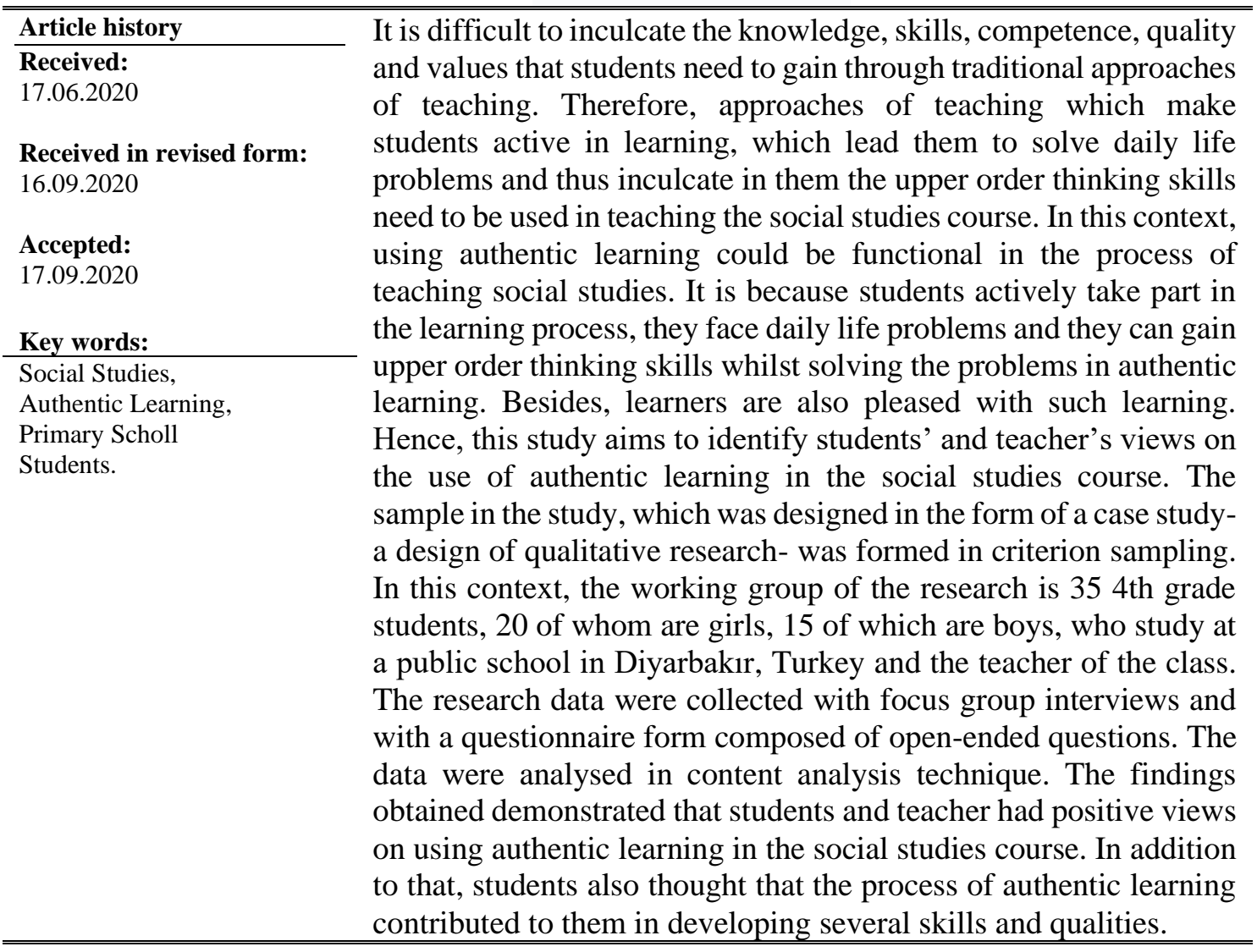

\section{Introduction}

The social Studies course has important functions in individuals' adaptation into social life, in gaining citizenship skills, in acquiring universal and national values and in gaining the knowledge, skills and competence necessary for contributing to the economic development of their country. It will be difficult for learners to gain such knowledge, skills and competence through traditional methods and techniques of teaching because it does not seem possible for students to gain the above-mentioned knowledge, skills, competence and values in the social studies course through teaching in which the teacher is active and the students are passive recipients (Kabapinar, 2012). Research has also demonstrated that the methods and techniques which make students active in social

\footnotetext{
*Correspondency: hanifi.sekerci@dicle.edu.tr, hnfskrc@gmail.com
} 
studies course can be more effective in inculcating the gains (Bengiç Çolak, 2015; Çakmak, 2007; Çalışkan, 2009; Doğan, 2008; Memişoğlu, 2008; Tuncel, 2007; Uysal, 2010; Y1ldırım; 2007; Yiğit and Erdoğan, 2008). One of the teaching approaches which makes students active and which enables students to use the acquired knowledge to use in the learning process is authentic learning.

Turkish word "otantik"- of which the English equivalence is authentic and which Turkish borrowed from French language- is defined as "the one which preserves its longstanding features and which is original" in Turkish dictionary (TLI, 2020). Authentic learning is built on bringing real life situations and objects into learning environments. According to Cholewinski (2009), authentic learning involves transferring the situations and problems in real life into learning environments. Besides, it is necessary to use real life objects in learning environments. There are also two different uses of authentic learning in educational environments. Lombardi (2007) states that authentic learning environments are likened to real world environments, that the focus in such learning environments is on the solution of complex problems of real life and therefore problem-based activities and case studies are included in such learning environments. The purpose in educational practices considered in the process of authentic learning is not to inculcate in students limited and superficial knowledge about a subject or to inculcate simple skills in them (Koçyiğit and Zembat, 2013: Reeves, Herrington \& Oliver, 2002). The main purpose here is to ensure that students acquire in-depth knowledge through practices based on collaboration, that they use their knowledge and that they gain upper order skills (Newman, Walter and Wehlage, 1993).

It can be said that authentic tasks have significant functions in students' being deeply informed of life problems and in their acquisition of upper order thinking skills. According to Rule (2001), students can use knowledge they have learnt at school in solving real life problems by means of authentic tasks. Yet, the tasks need to be uncomplicated, incompletely defined, suitable to students' levels and appropriate for collaborative work (Gündoğan and Gültekin, 2017; Young, 1993). The process of teaching- which starts with assigning the tasks- continues with authentic activities. Students should be able to collaborate in long-term work and reflect what they have learnt into their life in those activities. The process is focussed in evaluating the activities done and on whether or not students understand the rationale in authentic learning (Akça and Ata, 2009; Knobloch, 2003).

Authentic learning process has its own components. The components are taken into consideration in designing the process of learning. The components are called authentic context, authentic task, expert model, multiple roles and perspectives, collaboration, reflection, stating clearly, one-to-one raising and authentic evaluation. The component of authentic context contains the features of real-life problems and situations. Students' active participation in the solution of real-life problems is made through authentic tasks so that they can acquire knowledge and skills. According to the component of expert model, students can learn the reflections of a subject into real life through experts in authentic learning. In the component of multiple perspective, different perspectives can be employed in solving a problem. The component of collaboration lays emphasis on students' collaborative work to solve a problem. According to the component of reflection, students can state what they learn about a subject by making reflections. The component of stating clearly involves students' presenting their products to their friends. According to the component of one-to-one raising, the teacher works with students one- 
to-one and guides them. Evaluation, on the other hand, is made process-oriented in authentic learning (Bektaş and Horzum, 2014; Herrington and Oliver, 2000; Caseley, 2004; Şimşek, 2000; Renzuli, 1997). Students can acquire the knowledge and skills to be used in real life in learning environments which were created according to the abovementioned components, they can interact with their peers by collaborating with them, they can present the knowledge they have acquired freely, and thusly they can improve their cognitive, individual and social skills (Bektaş and Horzum, 2014; Wardekker, 2004; Gulikers, Bastiaens \& Martens, 2005; Herrington and Oliver, 2000).

Review of literature demonstrates that various studies concerning authentic learning are available. Studies conducted by Varley (2008) and Fook and Sidhu (2010) report students' statements of their satisfaction with the process of authentic learning. Bolin, Khrantsova and Saarnio (2005) found that authentic learning activities contributed to students' affective skills beside their cognitive skills. Additionally, Risko, Osterman and Schussler (2002) found that authentic learning improved students' problem-solving skills. Studies conducted in Turkey for different levels of education and for different courses found out that the process of authentic learning contributed to learners' positive attitudes towards a course and that it increased their achievement (Ayar and Yalvaç, 2010; Karakuş, 2006; Koçyiğit, 2011). It was also discovered that students had positive views on the use of authentic learning in the process of learning social studies in secondary schools (Önger, 2019). Yet, no studies identifying students' and teachers' views on the teaching of social studies in primary schools or ones presenting them altogether in Turkey or abroad were found in the literature. This study differs from others in this respect. It is believed to provide researchers, primary school teachers and programme development experts with significant knowledge and ideas since the process of authentic learning is evaluated from the perspectives of primary school students and primary school teacher in the present study. Thereupon, it seeks answers to the following questions:

- What are the primary school students' and participant teacher's views on the use of authentic learning in social studies course?

- What are the feelings and thoughts of primary school students regarding the use of authentic learning activities in Social Studies course?

- How did the teaching of the social studies course with authentic learning activities affect the perspective of Primary School students?

- What did the teaching of Social Studies course with authentic learning activities improve in students?

- What are the authentic learning activities enjoyed by primary school students in Social Studies course?

- What are the authentic learning activities in the Social Studies course that primary school students think which challenge them?

- How do primary school students view the use of authentic learning activities in different classes?

- What are the opinions of the classroom teachers participating in the study about the use of authentic learning activities in Social Studies course?

- How does the classroom teacher participating in the study view the use of authentic learning in different lessons?

- How does the classroom teacher participating in the study view the use of authentic learning in different lessons?

- What are the opinions of the classroom teacher participating in the study on the better implementation of authentic learning? 


\section{Method}

\section{Research Design}

This study uses case study- one of the qualitative research designs. According to Y1ldırım and Şimşek (2011), researchers scrutinise a phenomenon or an event in depth by focussing on questions such as how, why and what and concentrate on how the topic of research affects the study group. The use of authentic learning in teaching social studies was set as a case in this study, and efforts were made to find how the case had affected students' views. The design of holistic single case design was used in this paper. According to Yin (1984), holistic single case design is a type of case study used in cases where a single unit of analysis is available and a certain case is considered. The class where the implementation was done was set as the unit of analysis because the effectiveness of the case of using authentic learning in social studies course would be evaluated from the perspective of primary school students.

\section{The Study Group}

The study group was formed through criterion sampling- a technique of purposeful sampling- in this study. The units capable of meeting the set criteria (objects, events, etc.) are included in the sample in criterion sampling (Büyüköztürk, Kılıç Çakmak, Akgün, Karadeniz and Demirel, 2012). The criteria in choosing the participants in this study for the students were being the $4^{\text {th }}$ graders, not having done activities related to the learning domains of production, distribution and consumption, receiving permission from school administration and teachers for the research and teachers' participation on the basis of volunteering. In this context, the working group of the research is 35 th grade students, 20 of whom are girls, 15 of which are boys, who study at a public school in Diyarbakır as well as the teacher of the very class.

\section{Data Collection and Analysis}

The research data were collected through focus group interviews, open-ended student questionnaires and a semi-structured teacher interview form after authentic learning-based activities had finished. The relevant literature was reviewed, and an interim form was prepared while preparing the questions for focus group interviews, semi-structured teacher interview form and for open-ended questionnaires. Two experts of the area and a language expert were asked to analyse the interview forms. According to feedback from field experts, "What kind of changes occurred in their thoughts about this lesson after teaching the social studies lesson with authentic learning activities and "What would you like to say about this subject" contained in the focus group interview and open-ended questionnaires was seen as a guiding question. This question has been rearranged into "Did your thoughts about the social studies course change after teaching the course through authentic learning activities? What would you like to say in this respect?" Besides, "What kind of skills did teaching social studies course with authentic learning activities contribute to your development? What would you like to say about this topic?" question is, according to the translation from the language expert, for primary school $4^{\text {th }}$ graders may not be clear or understandable enough. "What has the processing of a social studies lesson with authentic learning activities enabled you to develop?" question has been rearranged in the form. As a result, the focus interview form contained 7 questions, the open-ended questionnaire form contained 6 questions and the semistructured teacher interview form contained 9 questions. 
The students completed the open-ended questionnaire in the classroom in a class hour. The focus group interviews was done in the part of the school which was used for implementations and activities with the participation of seven volunteering students. The interview lasted approximately 40 minutes. The interview with teacher lasted 30 minutes. The interviews were voice recorded. Prior to voice recording, the teacher and students' permissions were received. The recordings were then transcribed.

The data coming from the open-ended questionnaire and focus group interviews were put to content analysis. Yıldırım and Şimşek (2011) state that the main procedure to make in content analysis is to bring similar data together within the framework of concepts and themes, to arrange them in a way that readers can understand and then to interpret them. Thus, categories and themes were distinguished for each question in analysing the data. The participants' responses were included in the relevant categories and themes according to their properties. The data collected from the teacher were also included in the themes. In this way, the data were presented in a holistic manner and were interpreted. Code names were used in presenting the data.

\section{Validity and Reliability}

Criteria of persuasiveness, transferability, consistency and confirmability should be met for validity in qualitative studies (Cresswell, 2005; Yıldırım and Şimşek, 2011). The researcher himself collected the data in this study by using separate data collection tools in the long process of data collection to meet the criterion of persuasiveness. In addition to that, he consulted expert opinion by contacting the experts who were generally knowledgeable about the study and who had performed qualitative studies previously. The researcher also made efforts to describe all the stages and processes in detail so as to meet the criterion of transferability. Whence, detailed information was given in relation to data collection and analysis processes, and it was supported with direct quotations. In the context of consistency, the interviews were recorded with a voice recorder, and all of the open-ended questionnaire forms were collected. An impartial attitude was displayed to meet the criterion of confirmability, different experts were asked to analyse the research data and thus, agreement (consistency) between them was checked. In this way, efforts were made to attain validity in the research.

The analyses were also done by another expert in the area for the reliability of the study. The agreement between the two analyses was calculated with Miles and Huberman's (1994) formula of "Reliability= the number of agreements/the number of agreements + the number of disagreements". For both validity and reliability studies, the consistency between the analyses performed by experts and the analyses performed by the researcher was calculated as $90 \%$. Accordingly, the analyses can be said to be reliable.

\section{The Application Process}

This study was conducted so as to identify students' and teachers' views on the authentic learning activities conducted in primary school social studies classes. In accordance with the purpose of the study, efforts were made to inculcate in students the gains for the unit of "Production, Distribution and Consumption" in the Social Studies course through authentic learning activities in the context of aid campaign for war weary Syrian refugees. The reason for why the focus of the aid campaign was war weary Syrian refugees was that there was a great number of Syrian refugees in Diyarbakir, that the children could see the hardship that the refugees suffered at any moment of the day and 
that they had the thought that they could also suffer from it. Within the scope of the aid campaign, a story of six chapters was designed, and activities based on authentic tasks were created for each chapter. The activities and authentic tasks were related to the problems available in the story and they consisted of practices for solving the problems. The activities and plans prepared were regulated according to the views stated by domain experts who held a doctoral degree in teaching and performed studies in authentic learning. Details for the activities are described below.

Chapter one in the story contained the problem stated as "Hasan and his friends are in dispute over what to include in aid packages for Syrian people in need". Activities prepared for the problem on the basis of authentic tasks aimed to inculcate in students the gain of "discriminating demands from needs and making conscious preferences between the two." The problem was built upon some students' wish to include materials which were considered as demands rather than needs in the aid packages in the problem where Hasan and his friends were sending aid to war weary Syrian refugees. The problem was discussed with the students and then the activities were done. In activity one, visuals showing the problems war weary Syrians encountered were given to the students and a discussion was made on what essential needs those people might have. In activity two, visuals showing children watching a play at the theatre, having a picnic, and playing were shown to the students and a discussion was made on demands. In this way, they were made to distinguish between essential needs and demands. In the final activity, the students were asked to draw caricatures related to basic needs and demands as an authentic task. The students then showed their drawings to their classmates.

Chapter two contained the problem stated as "Ali does not look carefully into what he buys during shopping and he does not behave consciously." The authentic learning tasks prepared for the problem aimed to inculcate in students the gain of "displaying consumer behaviours as individuals with responsibility". The problem in the story was built upon the unconscious shopping done for the aid to be sent to war weary Syrians by the student called Ali. The students got into groups and they identified the problems Ali was probable to encounter and they presented the problems in the classroom. Afterwards, the students were given a worksheet on activities related to news about food control, and thus they were made to do activities about the importance of asking for receipts and certificates of warranty. The students made sense of the characteristics of conscious consumers. They were asked to prepare slogans about conscious consumption as an authentic task. They presented their slogans to their classmates in the classroom.

Chapter three in the story contained the problem stated as "Selin and her friends could not afford to do the shopping for aid package with their pocket money." The activities to be done for the problem aimed to inculcate in the students the gain of "setting a sample budget for oneself". The problem fictionalised in the chapter was the insufficiency of Selin and her friends' pocket money to buy materials of accommodation-which was a basic need. The students were assigned authentic tasks within the framework of the problem and thus the purpose was to get students to set a budget and to save money and also to organise an aid campaign by engaging others in the activity. In this way, the unit gains were associated with the authentic context. First, the story chapter was read whilst teaching the lesson and then a discussion was carried out on what Selin and her friends could do. The discussion focussed on the need for Selin and her friends to save money from their pocket money and to hold an aid campaign. After that, the visuals for the sample budgets of institutions and of families were shown to the students, and thus they 
understood the fact that budgeting secured to manage money and to balance the expenditures with income. In this chapter, the students were asked to prepare a budget for themselves and for their family as an authentic task. They prepared sample budgets. They also posed the opinion that Selin and her friends could solve their problem by preparing a budget in relation to the problem given in the chapter of the story. Besides, a young representative of Turkish Red Crescent organisation made a presentation on the aid that the Red Crescent provided the Syrians. Following the presentation, the idea of aid to the Syrians was discussed with the students and agreement was reached on holding an aid campaign. Accordingly, the students would prepare a budget they would spend on their basic needs and that they would put the remaining money into the moneybox prepared for the aid campaign. Additionally, they would also collect the usable clothes in their immediate environment and prepare an aid package. The aid campaign would last for three weeks.

Chapter four contained the problem formulated as "Anll is ignorant of the economic activities around him." The activities designed on the basis of authentic tasks for the problem aimed to inculcate the gain of "recognising the economic activities in the family and in the immediate environment". The problem posed in the chapter was about Anil's ignorance of his friends' efforts to raise money for the aid campaign and their mentioning the organisations and institutions around the school for the campaign since he took the school bus to commute. The problem was discussed with the students and then the visuals about economic activities in Diyarbakir were shown to them for the solution to the problem. The students identified the areas of economic activities in Diyarbakir by working in groups. They had a discussion about what occupations were available in the city in later activities. They were asked to write about the area in which they would invest if they were a businessman/businesswoman in Diyarbakır and to explain their reasons and then to present their writing in the classroom. The students made their presentation afterwards.

Chapter five included the problem stated as "Ahmet uses the resources carelessly and he wastes them"- which aimed to inculcate in students the gain of "using the resources in the environment without wasting them". The problem in the chapter was built on the fact that Ahmet wastes the resources around him by using them with no responsibility and that Ahmet and his friends witness the poverty of a Syrian girl called Leyla when they went to give the aid to the Syrians and that Ahmet is moved to tears on seeing Leyla. First, Ahmet's wasting the resources was discussed with the students. Then, the students were shown visuals about news on waste of food, water, electricity, and clothes; and the problems which might be caused by such waste were discussed with them. After that, a presentation was delievered about the work done by the municipality of a city to prevent waste of clothes, and the students worked in groups to find what they could talk to the major about the work of the municipality. The students talked about what was waste in their immediate environment and what they did to prevent it in the next lesson. They were asked to write the lyrics of a song, a poem, prepare a poster a brochure or to draw a caricature about what could be done to prevent waste. They made their presentation in the classroom. After that, they generated ideas in relation to what Ahmet should do.

In the final chapter, the money raised in three weeks and the clothes collected for the aid were submitted to the young representative of the Red Crescent to give to war weary Syrians. 


\section{Findings}

\section{The Findings for the Question of "What are the primary school students' and participant teacher's views on the use of authentic learning in social studies course"?}

The question of "what feelings and thoughts do you have about using authentic learning activities in social studies course?" was asked so as to determine the students' and the teacher's views on teaching social studies course through authentic learning activities. The themes which emerged for the students' and the teacher's responses to the question are shown in Table 1.

Table1. The students' and the teacher's views on the use of authentic learning in teaching the social studies course

\begin{tabular}{lll}
\hline Feelings and thoughts & f & \\
\hline Students' views & 11 & Teacher's views \\
Positive & 10 & Reneficial \\
Fun & 10 & Actention in learning \\
Beautiful & 7 & \\
Instructive & 4 & \\
Happy & 3 & \\
Exciting & 3 & \\
Enjoyable & 2 & \\
Nice & 2 & \\
Loving & 1 & \\
Joyful & 1 & \\
Wonderful & 1 & \\
Different & 3 & \\
Boring & & \\
\hline
\end{tabular}

According to Table 1, it can be said that the fourth graders have positive views on teaching the Social Studies course through authentic learning activities. Thus, it is apparent from the Table that the most frequently stated views are positive, fun, beautiful and instructive in relation to teaching the Social Studies course through authentic learning. For instance, the view stated by Ö13 as "different and positive because we learnt it through visuals containing news on newspapers" and "it was positive to me" was stated in the questionnaire form in writing. Ö2, on the other hand, made the statement "the lesson was great; I mean it was fun to me. I liked it very much." Ö21, in response to the question in open-ended questionnaire form, said, "Positive. I am joyful. All the classes were very good". In a similar way, Ö9 said that they found the way of teaching the lessons nice with the statement "I'm happy. We have seen pictures and watched videos. We have done nice work about the Red Crescent. We've helped, we've donated money and clothes." Ö35 stated his/her views about teaching the lesson as "I think it is something good. As to my feelings: happiness, love". The interview with the students demonstrated that students had positive views about the way lessons were taught. Ö33, for instance, said, "Nice. I liked it. It is nice to deal with real life problems. There is a bit of everything in the activities. Reading, writing, discussing, visual commentary.” In a similar way, Ö26 said, "I used to like social studies but not very much. Now I like it more. It is fun. I began to enjoy it. We learn new things; it develops our imagination we learn the things that are not in the book. I like it very much."

In addition to that, the teacher's views were also obtained. The teacher stated his views as " 1 t is very different from our techniques. The difference is good. It is not a difference 
to criticise. Our techniques are mostly teacher centred. I try to engage students but we are dependent on the curriculum and on the course book. Authentic learning makes children more active. There are more visual activities and the activities that kids can do. It is more beneficial than the current technique. Because students are fully engaged in the task. In this way knowledge is retained." According to the teacher, the learning activities make students more active. Besides, they make what is learnt more permanent. Therefore, it can be said that the teacher finds authentic learning activities beneficial for students.

Besides, it was also found that some of the students had negative views about the way lessons were taught. To exemplify, Ö34 stated the view as "It is sometimes boring. Because I sometimes feel bored." It can be said in general that both the students and the teacher were pleased with the use of authentic learning activities in teaching the social studies course. It was apparent from the findings that the number of students with positive views was relatively bigger than the number of students with negative views about teaching the course through authentic learning activities.

The students were asked the question "Did your thoughts about the social studies course change after teaching the course through authentic learning activities? What would you like to say in this respect?" after the practice to determine the effects of authentic learning process on their perspectives of the course. The themes which emerged in the analyses of students' answers to the questions are shown in Table 2.

Table 2. The changes in thoughts about the Social Studies Course

\begin{tabular}{ll}
\hline Thoughts which changed & f \\
\hline Change from dislike to like & 10 \\
Change from liking it to liking it more & 4 \\
Change from liking it little to liking it very much & 1 \\
Change from finding it boring to finding it fun & 5 \\
Understanding that it is beneficial & 1 \\
Enjoying it more now than in the past & 2 \\
Change from liking it to finding it boring & 1 \\
Thoughts which did not change & $\mathbf{f}$ \\
No changes & 4 \\
\hline
\end{tabular}

As is clear from Table 2, thoughts about the social studies course changed substantially after teaching it through authentic learning activities. Accordingly, the changes were mostly in the form of from dislike to like, from finding the course boring to finding it fun and from liking it to liking it more. It was also remarkable that the students understood that the course was beneficial to them after teaching it through authentic learning. In this respect, Ö26 said, "It opened up my horizon, I learnt new things, my love for the course increased. I began to study the social studies course when I went home. Because it began to be more fun. The subjects were not fun in the lessons in the past. But the subjects in your classes are fun and the activities were enjoyable." And thus, the student stated that he/she began to like the course more. The views stated by Ö6 were "I used to like the subjects in the social studies in the past but you enlivened the course more. I began to like it more in this way. Social studies course is more engaging in the way you teach." In addition to that, Ö34 stated his/her views in the open-ended questionnaire as "I didn't like it in the past but I like it now." Ö21 stated the changes in his/her views as "I didn't like it in the past but now I like it very, very much now." Ö25 stated the changes as "I used to like it very little in the past. Now I like it very much. Because the subjects were taught very nicely." Ö28 stated the changes in his/her thoughts about the course as "I used to like the social studies course but now I like it more because it is entertaining with the 
activities." Ö2 said, "I didn't like it in the past. Now I like it since it is more fun and interesting." The changes in the views of Ö23 were stated as "It was bad in the past because it didn't help. Now it is also interesting." Ö13 made the statement "I used to feel bored in the past. Now I don't feel bored. Because we used to read continuously in the past. Now, we learn in the social studies course through visuals and news items." It was also found in this study that authentic learning activities increased interest in the social studies course. Ö18, for instance, made the statement "I was not interested in it in the past. Now I enjoy it very much". Authentic learning activities also influenced students' thoughts about the benefits of the course. In this respect, Ö20 said, "I understood that the social studies course was very useful."

The teacher also stated that authentic learning activities affected the students' views on the social studies course in positive ways. Thereupon, during the interview, the teacher said, "Children are more active in this method. They are involved in the work in several activities. They themselves generate the ideas and they can have a discussion on these regardless of what is right or wrong. Such a situation affects their interest in the course and their perspectives in positive ways." Based on the views held by most of the students and also on the teacher's views, it may be said that authentic learning activities influence students' perspectives of the social studies course. No changes occurred in the students' thoughts about the course in general despite the fact that very few students stated that they no longer liked the course. To exemplify, Ö22- whose views did not change- said, "Nothing has changed for me. I used to like the social studies course in the past and I like it now, too. I have always liked it and I will always like it." Ö5, however, stated that he/she found the course taught through authentic learning activities boring by saying, "I liked the previous social studies course more. I feel bored with the course which is taught through authentic learning activities."

The students were asked the question "What developments did the process of teaching the Social Studies course through authentic learning activities cause in you?" to find "What the use of authentic activities in teaching the course developed in the students?". The themes which emerged from the students' answers to the question are shown in Table 3.

Table 3. The Skills, values and understanding that the students think the use of authentic learning activities have developed in them

\begin{tabular}{lll}
$\begin{array}{l}\text { The skills, qualities and values that } \\
\text { the students think have developed in } \\
\text { them }\end{array}$ & f & $\begin{array}{l}\text { The skills, understanding and qualities that the } \\
\text { teacher thinks have developed in the students }\end{array}$ \\
\hline Participation in group work & 8 & Development of personal thoughts \\
Expressive skills & 4 & Communication skills \\
Discussion & 4 & Understanding and awareness of different thoughts \\
Empathy & 2 & \\
Socialising & 2 & \\
Consumer awareness & 2 & \\
Imagination & 2 & \\
Horizon opened up & 1 & \\
Benevolence & 3 & \\
Sharing & 2 & \\
Respect & 1 & \\
Solidarity & 1 & \\
\hline
\end{tabular}

Accordingly, the fourth graders think that understanding and skills such as working in 
groups, discussing, self-expression, empathy, socialising and consumer awareness have developed in them in the social studies course taught through authentic learning activities. They also believe that such values as benevolence, solidarity, respect, and sharing have developed in them. Thence, the student coded as Ö33 said, "Group work made it more important for me to consider what is important and to internalise my friends' ideas. Things like considering important and showing respect became more important for me." Ö11 said, "group work was very nice. I shared my views with my friends and they also shared their ones with me. We wrote poems, we drew pictures. I liked those thigs"; and the student meant that he/she liked sharing with his/her friends. In relation to participation in group work, Ö22 said, in the open-ended questionnaire, "I learnt to act together as a group without hurting each other. It was the change for me. I learnt new things from them." Hence, it can be said on the basis of students' statements that the activities have developed understanding and awareness in students in terms of participation in group work. Some of the students said that their expressive skills had developed. Hence, Ö2 made the statement "I was able to say what I was going to say better. I was able to speak better." In a similar way, Ö1 said, "We made comments on the visuals, we described them by drawing caricatures." Accordingly, it can be stated that the students' expressive skills developed with the use of authentic learning activities.

Similar findings were also obtained in interviews with the teacher. The teacher believed that authentic learning activities had developed students' expression skills. The teacher described the situation in the statement "expressing, for instance, through caricatures, pictures. While some of the children could not express themselves verbally, they expressed themselves in different ways so nicely. You have opened the way for them to express themselves in different ways. In this respect, it was beneficial for the students." During the interviews, the teacher added, "The students' discussions about a subject for two-three minutes by generating ideas... It secured the communication between them. Those four children think that they say something and put forward an idea and that their friends listen to them and that they should also listen to their friends. Unfortunately, we are lacking, as the society, in listening to and understanding each other. In this sense, the students' listening to and understanding each other has developed their communication skills." It can be said in this sense that the teacher thinks that group work has developed the students' communication skills and that it inculcated in them awareness of and understanding in listening to and understanding the ideas of others. Again, the teacher's made the evaluation "For example, students' statement that there is war in Syria and the people who escape from war need help is a verbal expression. It is no longer verbal in authentic learning. Children themselves offer the help directly. They give up buying and eating ice cream or 'simit' and they put the money in the moneybox instead to raise money for aid. They themselves experience it. They no longer receive instructions. In my opinion, it is something that opens the way for individualism. Children have their own individual ideas, thoughts, and experiences in this respect."- which meant that authentic learning activities contributed to the development of children's individual thoughts and ideas.

It is clear from the Table that the students think discussion skills have developed in them. One of the students who had that idea was the participant coded as Ö3. The participant said, "Its contribution was to my discussion skill". In a similar way, Ö12 made the statement "We drew caricatures and pictures and discussed them with my friends" in the open-ended interview. Some of the participants thought that empathy skills had developed in them. Ö29, for instance, said, "I can understand people better in this way. I 
can empathise with them." Ö35, on the other hand, said, "I understood the Syrians better. I became a conscious consumer. Some other students thought that authentic learning activities developed their imagination. In this respect, Ö11 said, "We did the activities that nobody had done. We learnt the things that were not available in the book, it developed my imagination." It is apparent from the statements that the student believes that authentic learning activities have developed his/her imagination.

Besides, some students also thought that they became sociable. In an interview about what authentic learning activities had developed in them, Ö26 said, "you, my teacher, say something and I do research about it when I go home, so, it opens up my horizon. And I am also more sociable. I learnt what it was like to share in group work." Thus, it can be fair to say that authentic learning activities contribute to opening up students' horizon, to their socialising and to their learning alongside to their attaching importance to sharing. Another view was offered by Ö5 about sharing in the statement "I understood that sharing made people happy". In relation to the value of helping people, Ö20 said, "I understood that people should be helped. Ö9, in this respect, said, "Our development was in the form of learning about helping. We became more knowledgeable about it. In this sense, it can be said that authentic activities contributed to the development of benevolence. In relation to solidarity, Ö11 put forward his/her view: "My skills of solidarity and consultation with my friends have developed by means of group work." In this context, it can be said that authentic learning activities have contributed to the development of students' skills, consciousness and understanding.

The students were asked the question "What was the activity that you liked the most in the social studies course taught through authentic learning activities?" to determine the activities that they liked the most in authentic learning. The themes which emerged in the analysis of the students' answers to the question are shown in Table 4 below.

Table 4. The authentic earning activities the students liked

\begin{tabular}{ll}
\hline The activities liked the most & f \\
\hline Campaign of aid to the Syrians & 16 \\
The presentation made by the expert about the aid & 5 \\
given by the Red Crescent & \\
Budgeting & 4 \\
Activities about saving and wasting & 3 \\
Discussions & 3 \\
Activities on the worksheet & 3 \\
Drawing caricatures & 3 \\
All & 2 \\
Group work & 1 \\
Conscious consumer & 1 \\
Economic activities & 1 \\
\hline
\end{tabular}

It is evident from Table 4 that the students liked the activity of campaign for helping war weary Syrian families the most. For example, student Ö33 said in this respect, "I liked the campaign for helping the Syrians. It is because helping people makes me happy. I liked it when they received the aid and had a meal with it and bought clothes with it. It was an activity which increased the sense of sharing. "In addition to that, in the openended questionnaire, Ö12 also made the statement "I liked the campaign of aid to Syrians". In a similar way, Ö9 also listed the activities that he/she liked most in the statement "The activities that I liked: money aid to the Red Crescent, clothes aid. Because the Syrians need money and clothes." Additionally, the presentation made by the expert 
in the Red Crescent was one of the activities that the students liked the most. Ö25, for instance, said in this respect, "The activity of presentation by a Red Crescent official describing the aid to the Syrians was very nice. Ö13 also said, "The subjects about aid given by the Red Crescent, the activities about wasting were nice." Thus, the activity of expert opinion was one of the activities that the students liked. Ö21 stated his/her view about the subject as "the poems we had written about wasting and saving money were very beautiful." Some of the students were found to be enjoying budgeting activities in the interviews with them. To exemplify, Ö5 said, "I liked budgeting. It teaches us not to spend badly at the end of the month." In the interview about their favourite activities, Ö26 said, "My favourite activities are: conscious consumer and economic activities, these were nice. I liked the activity of investment. The two subjects were very nice too. And also budgeting." Thence, the student seemed to like the conscious consumer and economic activities in addition to budgeting activities.

Some students stated that they liked the discussion, caricature drawing and some of the worksheet activities. Student Ö4 said, "The discussions were nice because, in my opinion, it is enjoyable to share ideas. Ö5 stated that he/she liked the activities on the worksheet through the following sentence "The activities on the photocopied paper were nice." Another student, Ö31 gave the answer "Yes (, I liked them). For example, helping people. Activities such as pictures, caricatures and so on were also nice. Because we display our skills."

According to the Table, some of the students like all the activities and group work. In this respect, Ö28 made the statement "All the activities were nice. They were so nice that I couldn't choose one of these." Ö10 expressed his/her view as in the phrase "Group work and the activity in which we donated to the Red Crescent were nice."

The students were asked the question "Were there any activities which were difficult for you and which you did not like in social studies classes which were taught through authentic learning activities? What would you like to say in this matter?" to determine the activities in which they had difficulty and which they did not like. The themes which emerged in the analysis of the students' answers to the question are shown in Table 5.

Table 5. The Activities in which the Students had difficulty and which they did not like

\begin{tabular}{llll}
\hline Activities Disliked & f & $\begin{array}{l}\text { Activities students } \\
\text { had difficulty in }\end{array}$ \\
\hline Writing & 1 & Drawing caricatures & 8 \\
Generating ideas & 1 & Budgeting & 3 \\
Budgeting & 1 & Writing & 2 \\
& & Writing poems & 1 \\
& & Visual interpretation & 1 \\
\hline
\end{tabular}

It is apparent from Table 5 that most of the activities in which the students have difficulty and which they dislike are common to all students. For example, drawing caricatures, generating ideas about a problem and then writing about it and budgeting are the activities in which they have difficulty and which they dislike. In an interview, student Ö9 stated his/her view in this respect as "The activity in which I had difficulty was economic activities. We wrote too much in some activities and I had difficulty in them." The student was observed to have difficulty in the activity about economic activities in Diyarbakır since the students needed to generate ideas and write about them. Ö28, on the other hand, said, "I had difficulty in and bored with budgeting." In a similar vein, Ö9 said, 
"Budgeting. Because it didn't come to my mind". Caricature activities appeared to be amongst the most difficult activities for the students. In this respect, Ö6 answered the question in the open-ended questionnaire as "We were asked to draw caricatures and write poems in some activities. I had difficulty in them." Ö29 also stated his/her view as "I had difficulty in drawing caricatures and in interpreting the visuals." In this context, it can be said that activities of writing about a problem, writing a poem, generating ideas and interpreting visuals-which can be considered as activities which are at the analysis, synthesis and evaluation stage of cognition and which require higher order thinking skills- were challenging to the students.

The teacher also made similar evaluations in the interview in relation to the situation. The teacher made the statements "I think they had difficulties. Going out of the way they are taught and being taught differently and being asked questions. These put a heavier burden on them. Yet, it is not negative. Being involved directly in activities and generating ideas... It is not something that they are accustomed to. They were confused a bit because they are not used to such things here. But in my opinion the confusion was temporary. Then they enjoyed it. Of course, it is something beneficial to them." As can be understood from the teacher's statements, the activities to which the students were not accustomed, and which were cognitively at upper stages necessitating higher order thinking skills were difficult and boring for the students. Notwithstanding, it was also understood from the teacher's statements that the activities were beneficial to the students.

The students were then asked the question "Should authentic learning activities be used in other courses? What do you think of this?" The themes distinguished in the analysis of the students' answers are shown in Table 6 . In addition to that, the themes which emerged after the analyses at the end of the interview with the teacher are also shown in the Table.

Table 6. Other courses in which the students demand that authentic learning activities be used

\begin{tabular}{lll}
\hline $\begin{array}{l}\text { The students' views on the use } \\
\text { of authentic learning in other } \\
\text { courses }\end{array}$ & $\begin{array}{l}\text { The courses in which the } \\
\text { students want authentic } \\
\text { learning to be used }\end{array}$ & $\begin{array}{l}\text { The teacher's views on the use } \\
\text { of authentic learning in other } \\
\text { courses }\end{array}$ \\
\hline Fun & $\begin{array}{l}\text { Mathematics } \\
\text { Turkish } \\
\text { Facilitating }\end{array}$ & $\begin{array}{l}\text { Active participation } \\
\text { Academic achievement }\end{array}$ \\
\hline
\end{tabular}

According to Table 6, the findings obtained from interviews with students demonstrate that a considerable number of students demand that the courses of mathematics, Turkish and physical sciences be taught through authentic learning activities since such activities make learning subjects fun and easy. Accordingly, the student coded as Ö26 said, "the activities we did were greatly fun, and I liked them. Mathematics is very boring. And some of the subjects are difficult. It would be more fun and nicer if we learnt them in this way." Ö11, in the same way, made the statement "I would especially like to have it in mathematics. I have difficulty in mathematics. It will be fun and easier if we learn it in this way. And I also like to have it in other courses". Ö9 held the view stated as "It was boring in the way our teacher taught us. It could have been more fun in mathematics and Turkish and in physical sciences". In this context, it may be said that the students find the use of authentic learning activities in different courses positive due to the fact that they make subject easier and fun. The teacher's evaluation in this respect was as in what follows: "I am not fully competent in the matter but it can make subjects more meaningful when we consider it on the basis of subjects; for example in mathematics by using real 
life problems. The method engages children directly in the work. I think that it can be beneficial academically if we engage students in the solution of mathematical problems. It can also be useful in other courses. It should be thought over, activities should be prepared." It is apparent that the teacher thinks authentic learning activities can be used in mathematics because they make students active and because they make subjects more meaningful for students. The teacher is also positive in using authentic learning in other courses.

Some of the students did not think using authentic learning activities in different courses was appropriate. On examining such negative views, the researcher encountered statements which were not fully comprehensible- such as damaging the properties of a course if used in it. The interviews with the students indicated that the students did not find teaching other courses in the way social studies course was taught appropriate. For example, Ö33 said in this respect, "In my opinion, if they are used in other courses, they damage the properties of those courses. I wouldn't like mathematics to be taught like social studies course is taught." Yet, such views cannot be said to be related to authentic learning. Such views stated by students can be attributed to the fact that they do not have experience with authentic learning activities in other courses.

The question "What criticisms and recommendations do you have for implementing authentic learning better?" was asked in order to determine the criticisms for implementing authentic learning better and for the implementation. Table 7 below shows the themes which emerged by analysing the teacher's answers to the question.

Table 7. The teacher's views on how to implement authentic learning better

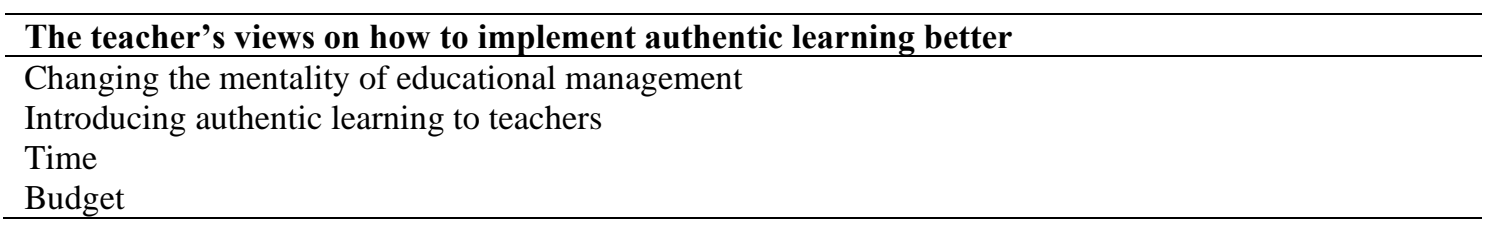

As is clear from Table 7, the teacher interviewed in the research thinks that budget should be made, mentality of educational management should be changed, authentic learning should be introduced to teachers and more time should be allocated so that authentic leaning can be implemented better. In this respect, the teacher said, "In my opinion, budget is needed to implement it effectively. When teaching the production of animal products, for instance, it is necessary to take children to the place where the production is made- perhaps a factory for learning by doing and by experiencing. Budget is needed for it. When we go to school directors for having such an activity, it is highly probable that they will say there is no need for it. The management in the ministry and in schools should change their mentality. And authentic learning should be introduced to teachers. That is to say, work similar to the one you did with us should be done more frequently. Also, time. Authentic learning activities require more time."

\section{Conclusion and Discussion}

The findings obtained in this study demonstrated that students had positive views on teaching the social studies course through authentic learning activities. Thus, the students found the activities positive, fun, beautiful, enjoyable, and nice. In a similar way Nicaise, Gibney, Crane (2000) also found that students considered their authentic learning experiences as fun and exciting. Heinitz (2012) observed that students had fun in the 
process of learning through authentic writing tasks and that they liked sharing their writing with listeners. Chen et al (2013) demonstrated that students enjoyed authentic learning activities which were done by forming a digital learning platform. Hamurcu (2016) found that students stated positive views such as fun, beautiful, etc. about authentic learning activities used in teaching Turkish course. Belet Boyac1 and Güner (2017) demonstrated that primary school students liked doing activities through blogs in authentic environments in Turkish classes. Önger (2019), on the other hand, found that using authentic learning activities in social studies classes made classes entertaining for students. Wornyo, Klu \& Molhaka (2018), similar to other studies, revealed that students were deeply informed of authentic learning tasks and activities, that they found the activities beneficial and that they expressed their satisfaction with them. Consequently, the results obtained in this study could be said to be in parallel to the ones obtained in other studies.

Authentic learning activities have changed students views on the social studies course significantly. In this context, the views most frequently stated by the students in this study were the changes "from dislike to like", "from finding it boring to finding it fun" and "from liking it to liking it more". Therefore, it can be highlighted that authentic learning activities have influenced students' thoughts on and perspectives of the social studies course in positive ways. In a similar vein, Önger (2019) also found that authentic learning had affected secondary school students' perspectives of the social studies course positively. Karakuş (2006) found that constructive learning and authentic evaluation activities had positive impacts on students' attitudes towards the social studies course. The positive effects of authentic learning on students' attitudes towards a course were also found in other studies. Accordingly, the positive effects of authentic learning activities on prospective teachers' attitudes towards the social service practice course were the finding obtained in Horzum and Bektaş (2012) whereas the positive effects of authentic learning activities on primary school students' attitudes towards the social studies course were the finding obtained in Gündoğan (2017). Thus, the findings obtained in this study may be said to be consistent. Apart from that, Lee and Goh (2012) found that authentic learning also influenced attitudes towards school. In this context, it can be claimed that authentic learning activities can influence attitudes towards and thoughts about school beside influencing attitudes towards and views on courses.

It was another conclusion obtained in this study that students thought authentic learning activities had developed their skills of participation in group work, socialisation and communication. Anwari et al (2015) found that students could learn subjects better and that they improved their communication skills in group work activities done in authentic learning. Hamurcu (2016), on the other hand, found that group work activities enabled students to understand each other better and to learn subjects better. Luo, Murray and Crompton (2017) point tout that group work enables students to have levels of interaction. Gürdoğan and Aslan (2016), in a similar way, observed that prospective teachers' cooperation and communication skills developed in the process of authentic learning. Thus, the results obtained in this study have significant similarities to the ones obtained in the literature.

According to the conclusion, students think that their expressive skills have developed in the process of authentic learning. Güner (2016) also obtained similar findings. Accordingly, the fourth graders' writing skills developed in the process of authentic learning. Karadăg and Kayabaşı (2011) report that students think learning through 
authentic materials develop their expressive and personal skills. Based on the findings mentioned above, it can be said that the findings obtained in this study are similar to the ones observed in the literature.

The students in this study are of the opinion that the activities done in the process of authentic learning had developed their empathising skills. Similar to this finding, Hamurcu (2016) also demonstrated that authentic learning developed students' empathising skills. The students also hold the belief that authentic learning activities developed their imagination and that they opened up their horizon. According to Akça and Ata (2009) authentic learning supports creativity at the level of secondary education while it supports creativity at the level of higher education according to Yeen-Ju, Mai and Selvaretnam (2015). In this context, it can be said that authentic learning activities lead students to different thoughts, develop their imagination and thus support their creativity skills.

The conclusions demonstrated that the authentic learning activities were challenging especially at the beginning. Kinay and Bağçeci (2017) also detected a number of problems at the beginning of authentic learning process. Koçyiğit (2011) also obtained similar findings. Accordingly, prospective teachers- the participants in their research- were found to have difficulty in the parts of authentic learning which required practice.

The teacher included in this study found authentic learning activities positive for use in other courses since they made students active whereas the students included in this study found the activities positive because they made subjects easier and fun. Students' demand for using authentic learning activities in teaching other courses as they were fun and because they made students active was an expected result. In a similar fashion, Pullu (2019) determined this in her study. Students who take a programming course at the higher education level with activities based on authentic learning look positively at the use of different lessons because they think that authentic activities make the learning process fun. In this regard, it can be said that there is consistency between the research findings.

The teacher who took part in this study stated that more time might be needed for implementing authentic learning better. Karakoç (2016) and Aydın Aşk (2016) also obtained similar findings. The fact that authentic learning activities focus on solving real life problems and that they contain a number of components may hinder teachers to finish the target activities in the time predicted.

\section{Limitations and Recommendations}

This study found that primary school students had positive views on the process of authentic learning in the social studies course. Besides, a considerable number of the students wanted authentic learning activities to be used in differing courses since the activities made courses easy and fun. To this end, teachers can organise the learning content and experiences on the basis of authentic learning activities in courses that students become bored and have difficulty differing grade levels. The use of such activities in different courses can be investigated by researchers. Curriculum development experts, domain experts and course book writers can use activities suitable for authentic learning in social studies course book. In addition to that, they can prepare activities suitable for the process of authentic learning and can investigate the effectiveness of the 
activities.

The teacher interviewed in this study stated that authentic learning activities could take longer time than expected in the curriculum. Therefore, curriculum developers could consider it in preparing the content related to authentic learning process. Researchers should do their work in relation to this finding by cooperating with the teacher- the practitioner of the curriculum. The teacher also thought that the mentality of management of the Republic of Turkey Ministry of National Education (MNE) should be changed so that authentic learning activities could be implemented more effectively. It could be recommended that the legal procedures be implemented more rapidly and that such activities be encouraged by management in the MNE. The teacher interviewed also said that teachers were not very familiar with or did not recognise authentic learning. Therefore, educational faculties should cooperate with the directorates of national education to make practising teachers familiar with authentic learning.

This paper has demonstrated primary school students' views on the process of authentic learning in the social studies course in accordance with its purpose. It is also the limitation of this study. It was suggested in the literature that the process of authentic learning could develop higher order skills such as problem solving, creative thinking and critical thinking. Hence, researchers could also do action research or conduct experimental studies on the effectiveness of authentic learning in developing higher order thinking skills in primary schools.

\section{References}

Akça, N., \& Ata, B. (2009). The implementation of the authentic activities in high school history lesson and its problems.5. The Nature of Learning and Evaluation Symposium, İzmir Private Tevfik Fikret Scholls, İzmir. Retrieved from http://www.acikarsiv.gazi.edu.tr/index.php?menu=2\&secim=4\&txtDocType=3 .

Anwari, I., Yamada, S., Unno, M., Saito, T., Rahma Suwarma, I., Mutakinati, L., \& Kumano, Y. (2015). Implementation of authentic learning and assessment through STEM education approach to improve students' metacognitive skills.K-12 STEM Education, 1(3), 123-136.Retrieved from https://www.learntechlib.org/p/209546/.

Ayar, M. C., \&Yalvaç, B. (2010). A sociological standpoint to authentic scientific practices and its role in school science teaching.AhiEvran University Journal ofKırşehir Faculty of Education, 11(4), 113-127. Retrieved from http://www.acarindex.com/dosyalar/makale/acarindex-1423907673.pdf

Aydın Aşk, Z. (2016). The study of authentic task focused learning process in the maths course: An action research. (Unpublished doctoral thesis). University of Gaziantep, Gaziantep

Bektaş, M., \&Horzum, M.B. (2014). Otantik öğrenme [Authentic learning]. Ankara: Pegem.

Belet Boyac1, Ş. D.\& Güner, M. (2017). Views of students and teachers about use of technological authentic environment in Turkish language course.Anadolu Journal of Educational Sciences International, 7(1), 35-71.

Bengiç Çolak, G. (2015). The role of service learning approach in citizenship education in the social studies course. (Unpublished doctoral thesis). University of Marmara, İstanbul. 
Bolin, A.U., Khramtsova, İ., \&Saarnio, D. (2005). Using student journals to stimulate authentic learning: Balancing Bloom's cognitive and affective domains, Teaching of Psychology, 32(3). Retrieved from https://www.researchgate.net/publication/228636895_Using_Student_Journals_t o_Stimulate_Authentic_Learning_Balancing_Bloom's_Cognitive_and_Affective _Domains

Büyüköztürk, Ş., Kılıç-Çakmak, E., Akgün, Ö. E. \&Demirel, F. (2012).Bilimsel araştırma yöntemleri [Scientific research methods]. Ankara: Pegem.

Chen, G, D., Nurkhamid, Wang, C, Y., Yang, S, H., Lue, W, Y.,\& Chang, C, K. (2013). Digital learning playground: Supporting authentic learning experiences in the classroom. Interactive Learning Environments, 21(2), 172183.https://doi.org/10.1080/10494820.2012.705856

Cholewinski, M. (2009).An Introduction to constructivism and authentic activity.Journal of The School of Contemporary International Studies Nagoya University of Foreign Studies, 5, 283-316. Retrieved from https://nufsnuas.repo.nii.ac.jp/?action=pages_view_main\&active_action=repository_view_ main_item_detail\&item_id=233\&item_no=1\&page_id=13\&block_id=17

Creswell, J. W. (2005). Educational research: Planning, conducting and evaluating quantitative and qualitative research (2.ed.). New Jersey: Pearson Education.

Çakmak, G. (2007). The effectiveness of learning activities based on constructive theory in the unit 'the adventure of democracy' for grade 6 social studies. (Unpublished master's thesis). University of Marmara, İstanbul.

Çalışkan, H. (2009). Effectiveness on critical thinking skills of inquiry-based learning approach in social studies teaching. Kastamonu Education Journal, 17(1), 57-70. Retrieved from https://dergipark.org.tr/tr/download/article-file/817981

Caseley, P.M. (2004). Towards an authentic pedagogy: an investigation of authentic learning instruction in a middle school. (Unpublished master's thesis). Pacific Lutheran University, Washington.

Doğan, Y. (2008). The use of written historical evidences in social studies teaching. (Unpublished doctoral thesis).University of Gazi, Ankara.

Fook, C. Y., \& Sidhu, G.K. (2010). Authentic assessment and pedagogical strategies in higher education. Journal of Social Sciences, 6 (2), 153-161. Retrieved from http://citeseerx.ist.psu.edu/viewdoc/download?doi=10.1.1.977.5553\&rep=rep1\& type $=$ pdf

Gulikers, J. T., Bastiaens, T. J., \& Martens, R. L. (2005). The surplus value of an authentic learning environment. Computers in Human Behavior,21(3), 509521.doi:10.1016/j.chb.2004.10.028

Gündoğan, A. (2017). The reflection of the attitudes and learning processes to learning environments with authentic tasks in life science class.(Unpublished doctoral thesis).University of Anadolu, Eskişehir.

Güner, M. (2016).The effects of authentic task-based authentic material usage on students' reading comprehension, writing skills and writing motivation.(Unpublished master's thesis).University of Anadolu,Eskișehir.

Gürdoğan, M., \&Aslan, A. 2016).Sınıf öğretmeni adaylarının otantik öğrenme yaklaşımı hakkındaki görüşleri/Primary school teacher candidates' opinions about authentic learning approach].Science Teaching Journal, 4(2), 114-140. Retrieved from https://dergi.fead.org.tr/wp-content/uploads/G\%C3\%BCrdo\%C4\%9Fan-veAslan_42_114-140_2016.pdf

Gündoğan, A. \& Gültekin, M. (2018). The reflection of the attitudes and learning processes to learning environments with authentic tasks in life science class. 
Pegem Ĕğitim ve Ö̈̆retim Dergisi, 8(4), 771-832, http://dx.doi.org/10.14527/pegegog.2018.030

Hamurcu, G. C. (2016). The effect of authentic learning on students' problem solving and reading comprehension skills, as well as their attitude towards the course in elementary education's 7th grade Turkish language.(Unpublished doctoral thesis).University of İnönü, Malatya.

Heinitz, S.M. (2012). The effect of using an authentic writing task on students' attitudes toward writing.(Master Thezis), Martin Luther College, Minnesota.

Herrington, J.,\& Oliver, R. (2000).An instructional design framework for authentic learning environments. ETR\&D, 48(3), 23-48. https://doi.org/10.1007/BF02319856

Horzum, M.B.,\& Bektaş, M. (2012).The effect of authentic learning on preservice teachers' attitude and satisfaction towards service learning.Kastamonu Education Journal, 20(1), 341-360. Retrieved from https://dergipark.org.tr/en/download/article-file/806944

Kabapınar, Y. (2012). Kuramdan uygulamaya hayat bilgisi ve sosyal bilgiler ögrretimi [Life studies and social studies teaching from theory to practice]. Ankara: Pegem.

Karadağ, R.,\& Kayabaşı, B. (2011).Using newspaper columns as reading texts to develop writing expression skills. Turkish Studies, 6 (3), 989-1010. Retrieved from https://www.researchgate.net/profile/Ruhan_Karadag/publication/271022310_U sing_Newspapers_to_Improving_Writing_Skills/links/563894fd08ae7f7eb1859a 6b.pdf

Karakoç, B. (2016). Investigating the effectiveness of the authentic task based practices to the foreign language teaching. (Unpublished Doctoral Thesis). University of Gaziantep, Gaziantep.

Karakuş, F. (2006). The effect of constructivist learning and authentic assessment approach on social studies teaching students? academic achievement retention and attitudes towards social studies. (Unpublished Doctoral Thesis).University of Çukurova, Adana.

Kinay, İ.,\&Bağçeci, B. (2017).The examınatıon of ınfluence of authentıc assessment approach on prospective teachers' beliefs towards learning and participative assessment. Dumlupinar University Journal of Social Sciences,52, 16-32. Retrieved from https://dergipark.org.tr/en/download/article-file/304749

Knobloch, N. A. (2003). Is experiential learning authentic?. Journal of Agricultural Education, 44(4), 22-34. Retrieved from https://pdfs.semanticscholar.org/751e/8a514a2cea53913f64e438d2e7b3f220a93 c.pdf

Koçyiğit. S. (2011) The effects of the authentic task based constructivist approach on preservice teachers? achievement, attitudes towards classes and problem solving skills. (Unpublished doctoral thesis).University of Marmara, İstanbul.

Koçyiğit, S.,\&Zembat, R. (2013).Theeffects of the authentic task on preservice teachers' achievementi.H.U.Journal of Education, 28(3), 291- 303. Retrieved from https://dergipark.org.tr/tr/download/article-file/87216

Lee, S., \& Goh, G. (2012). Action research to address the transition from kindergarten to primary school: Children's authentic learning, construction play, and pretend play. Early Childhood Research and Practice, 14(1) Retrieved from https://files.eric.ed.gov/fulltext/EJ975650.pdf

Lombardi, M. M. (2007). Authentic learning for the 21st century: An overview. Educause Learning Initiative. Retrieved from https://www.researchgate.net/profile/Marilyn_Lombardi/publication/220040581 
_Authentic_Learning_for_the_21st_Century_An_Overview/links/0f $317531744 \mathrm{e}$ edf4d1000000.pdf

Luo, T., Murray, A., \& Crompton, H. (2017).Designing authentic learning activities to train pre-service teachers about teaching online.International Review of Research in Open and Distance Learning, 18(7), 141157.https://doi.org/10.19173/irrodl.v18i7.3037

Memişoğlu, H. (2008). Project based learning approach in teaching of the social sciences course. (Unpublished doctoral thesis).University of Gazi, Ankara.

Miles, M. B.,\&Huberman, A.M. (1994).An expand sourcebook: Qualitative dataanalysis. USA: Sage Publication.

Newman, F. M., Walter, G. S.,\&Wehlage, G.G. (1996).A guide to authentic instruction and assessment: Vision, standards and scoring. Madison: WI: Wisconsin Center for Education Research.

Nicaise, M., Gibney, T.,\& Crane, M. (2000).Toward an understanding of authentic learning: student perceptions of an authentic classroom.Journal of Science Education and Technology, 9(1), Retrieved from https://link.springer.com/content/pdf/10.1023/A:1009477008671.pdf

Önger, S. (2019). The authentic learning approach in social studies teaching: An action research study.(Unpublished doctoral thesis).University of Gazi, Ankara.

Pullu, E. K. (2019). The effect of authentic task-based practices in programming teaching on students' academic achievement, attitudes, problem solving and creative thinking skills. (Unpublished doctoral thesis).University of Firat, Elazı̆g.

Reeves, T. C., Herrington, J., \& Oliver, R. (2002). Authentic activities and online learning.HERDSA.

Conference http://elrond.scam.ecu.edu.au/oliver/2002/Reeves.pdf

Renzulli, J.S. (1997). How to develop an authentic enrichment cluster. Retrieved from https://files.eric.ed.gov/fulltext/ED420954.pdf

Risko, V. J., Osterman, J. C.,\& Schussler, D. (2002).Educating future teachers by inviting critical inquiry. Retrieved from https://files.eric.ed.gov/fulltext/ED466471.pdf

Rule, A. C. (2006). Editorial: The components of authentic learning. Journal of Authentic Learning, 3(1), 1-10. Retrieved from

Şimşek, A. (2000).Özgürlükçü öğrenme[Libertarian learning].In A. Şimşek, A. (Ed).Sinıfta demokrasi[Democracy in the classroom], Ankara: Eğitim Sen .

Turkish Language İnstitution [TLI]. (2020).Türk dil kurumu büyük Türkçe sözlük [Turkish language institution big Turkish dictionary].

Tuncel G. (2007) The effects on subjects of social studies lesson of instructional practises based constructivist learning approach. (Unpublished doctoral thesis). University of Marmara, İstanbul.

Uysal, G. (2010). The effects of cooperative learning on students achivement on elementary school social studies, problem solving skills, learning styles and the views of student. (Unpublished doctoral thesis). University of Dokuz Eylül, İzmir.

Varley, M. A. (2008). Teachers' and administrators' perceptions of authentic assessment at a career and technical education center. (Unpublished doctoral thesis). The Fordham University, New York.

Wardekker, W. (2004). Moral education and the construction of meaning. Educational Review, 56(2), 183-192. https://doi.org/10.1080/0031910410001693263

Wornyo, A. A., Klu, E. K., \& Motlhaka, H. (2018). Authentic learning: Enhancing learners' academic literacy skills. International Journal of Applied Linguistics \& English Literature, 7(4), 56-61. http://dx.doi.org/10.7575/aiac.ijalel.v.7n.4p.56 
Yeen-Ju, H. T., Mai, N., \&Selvaretnam, B. (2015). Enhancing problem-solving skills in an authentic blended learning environment: a Malaysian context. International journal of information and education technology, 5(11), 841.

Yıldırım, A., \&Şimşek, H. (2011).Sosyal bilimlerde nitel araştırma yöntemleri [Qualitative research methods in Social Sciences]. Ankara: Seçkin.

Y1ldırım, S. (2007).The influence of project-based learning model on the realization level of research skills in the social science lesson of the 4th grade primary school students.(Unpublished master's thesis).University of Marmara, İstanbul.

Yiğit, E. Ö., \&Erdoğan, T. (2008). Sosyal bilgiler dersinde uygulanan öyküleştirme yönteminin ilköğretim altıncı sınıf öğrencilerinin yaratıcı düşünme düzeylerine etkisi[Theeffect of the storyline method applied in the social studies course on the creative thinking levels of the sixth grade students in primary education]. C..U. Journal of Social Sciences Institute, 17(3),399-416. https://dergipark.org.tr/en/pub/cusosbil/issue/4380/60089

Yin, R.K. (1984). Case study research: Design and methods. California: Sage Publications.

Young, M. F. (1993). Instructional design for situated learning.ETR\&D, 41(1), 4358.https://doi.org/10.1007/BF02297091 